\title{
Making connections: creating relationships with nonhuman nature, place and community
}

\author{
Sally Birdsall ${ }^{1}$ and Peta White ${ }^{2}$ \\ ${ }^{1}$ University of Auckland, New Zealand and ${ }^{2}$ Deakin University, Australia
}

Following the New Zealand Association for Environmental Education's (NZAAEE) and Australian Association for Environmental Education's (AAEE) biennial conferences in 2018, all delegates were invited to further develop their presentations into scholarly academic papers that could be peer-reviewed and published in this journal issue. Four delegates/groups of delegates responded to this challenge. These four papers can be seen through the lens of making connections. Forming and maintaining connections are an intrinsic part of environmental and sustainability education - connections with nonhuman nature, with place and with our community.

Researchers in the environmental and sustainability education field are acknowledging that education programmes are just not working (Bryan, 2020; Monroe et al., 2017; Taylor, 2017). At the heart of this issue is the realisation that simply learning about an issue, such as the climate emergency, will not necessarily result in people making lifestyle decisions that will reduce their carbon impact. As sustainability educators, we need to move beyond teaching knowledge that aims to result in behaviour change, but instead focus on educating a 'whole' person, who is autonomous and self-reflexive, and can take a critically informed role in society (Sterling, 2010; Wals \& Benavot, 2017). In order to bring about this change, our learners need to make connections - with nonhuman nature, with their place and with their community.

Making connections not only involves cognitive learning but also affective learning. This dimension is seen by some researchers as the 'missing link' in education as it recognises learners as 'feeling-thinking' beings (Bryan, 2020, p. 10). Connecting with nonhuman nature is regarded as the crucial shift that we humans need to make, so that we consider the consequences of our actions on other living things when we make decisions about our lives. This way of thinking is termed as developing a relational worldview, where humans see themselves as part of, and interconnected with all of nature, a way of thinking can break down the binary of humans and nature (Stevenson, 2007). Indigenous cultures, for example, Aotearoa New Zealand Maori people, who trace their ancestry backwards in time to Ranginui (Sky Father) and Papatuanuku (Earth Mother) from whom all life on Earth originated (Marsden, 2003), express their whakapapa as originating with these Gods, hence their connectedness to all of nature.

Connections also need to be built with our 'place'. Feeling personally and emotionally connected to one's place is another element needed in environmental and sustainability education (Wals \& Benavot, 2017). This type of learning involves not just learning about one's place, but it also means developing an attachment to and concern for its wellbeing (Gruenewald, 2003) through lived experiences and hands-on engagement. As a result of this knowing and feeling, humans develop feelings of responsibility for their place, want to care for it and work to create and/or maintain a 'healthy' place.

The third type of connection is building connections with one's community. Such a connection helps learners to become part of diverse groups who, despite their differing values and interests, can work together on community projects (Wals \& Benavot, 2017). Furthermore, it is while we 
work together to take action that feelings of hope for our future are evoked. Ferreira (2019) argues that connections with one's community is what is missing in education because learners who can work with others to actively shape their community, city or nation is what will create change. Current education has focused on individual action-taking, and while of value, this type of action is not concerned with challenging current practices or confronting unsustainable structures in society. Therefore, if we want to effect change, building connections with one's community is crucial.

It is the interweaving and building of these three types of connections that could help us journey towards a more sustainable and hopeful future for all - human and nonhuman living things. Each of the four papers explores one or more of these connections.

The first paper, Where is the love in environmental education research? A diffractive analysis of Steiner, ecosomaesthetics and biophilia, explores the location of love in environmental education research through examining the relationality between human and nonhuman nature - the connections between people and other living organisms. Inspired by a contribution from the research symposium held at the AAEE conference, these authors explored how love forms the foundation of teaching and research praxis in environmental education. Using a diffractive analysis that explores hidden meanings, it is argued that since love is both innate and of the heart, it could become a way of knowing to help people reconnect both with themselves and nonhuman nature. It is also suggested that future research could focus on a spiritual dimension, which is part of traditional wisdom and ways of knowing, doing and being.

Similarly, to the first paper that draws on a post-qualitative lens, the second paper, Entanglements of matter and meaning: The importance of the philosophy of Karen Barad for environmental education, shares insights about Karen Barad's theory of agential realism as a way of articulating and engaging with connectedness that is inherent in everything in our world. This contribution shares conversations that took place during a workshop at the research symposium at the AAEE conference, where people engaged in collective learning with Barad's key ideas about phenomena, intra-action, material-discursivity and diffraction. Following small group learning, people came together and identified four ripples of agential realist theory that are pertinent for environmental education praxis. These ideas have relevance and implications for us all as environmental educators, since they encourage us to consider the 'other' and view ourselves as being in the 'fullness of the relationality of self-other, human and nonhuman' as we move towards this possibility of change.

The third, Lookout for learning: Exploring the links between drama and environmental education paedagogies, is an empirical study that investigates children's participation in a drama performance and its effects on their feelings of connection to their city - their 'place' in the world. Through a carefully crafted preparation process, these children were able to hold conversations with adults during a performance about the possible future of Auckland and were able to envisage themselves in a better future through their learning. As a result, the children aspired to make Auckland a better place in which to live, with some identifying new behaviours they had adopted to improve their environment, for example, walking more often instead of taking a car and not using plastic cling film. Key features of this programme are identified for other environmental educators who wish to integrate drama into learning are given.

The final paper in this collection, Interpretations of sustainability beyond the middle class, is also an empirical study that explores the ways in which people who are not engaged in dominant sustainability discourses make connections to principles and practices of sustainability. While sustainability is a construct, it underpins issues that are implicated in people's everyday lived experiences. When exploring what was perceived as important by these groups of people, it was found that connectedness to people and places were key for the construction of 'a good life'. Feelings of belonging to a family were important. However, what is more intriguing is the relationship identified between people's experiences in physical spaces and their sense of social connectedness. Findings showed that spending time in places promoted people's sense of belonging to a place, which in turn amplified their sense of social connectedness. This amplification 
occurred even though some people viewed physical space as external to their everyday world. These findings have implications for environmental educators in that they highlight the importance of interconnectedness between people and place but also illustrate the need for more nuanced environmental education programmes that go beyond the mainstream sustainability discourses.

\section{References}

Bryan, A. (2020). Affective pedagogies: Foregrounding emotion in climate change education. Policy \& Practice: A Development Education Review, 30, 8-30. https://www.developmenteducationreview.com/issue/issue-30/affectivepedagogies-foregrounding-emotion-climate-change-education

Ferreira, J. (2019). The limits of environmental educators' fashioning of 'individualized' environmental learners. The Journal of Environmental Education, 50(4-6), 321-331. DOI: 10.1080/00958964.2019.1721769

Gruenewald, D. (2003). Foundations of place: A multidisciplinary framework for place-conscious education. American Educational Research Journal, 40(3), 619-54.

Marsden, M. (2003). The woven universe: Selected writings of Rev. Maori Marsden. New Zealand: Estate of Rev. Maori Marsden.

Monroe, M.C., Plate, R.R., Oxarart, A., Bowers, A., \& Chaves, W.A. (2017). Identifying effective climate change education strategies: A systematic review of the literature. Environmental Education Research. http://dx.doi.org/10.1080/13504622. 2017.1360842

Stevenson, R. (2007). Schooling and environmental /sustainability education: From discourses in policy and practice to discourses of professional learning. Environmental Education Research, 13(2), 265-285.

Taylor, A. (2017). Beyond stewardship: Commonworld pedagogies for the Anthropocene. Environmental Education Research, 23(10), 1448-1461. DOI: 10.1080/13504622.2017.1325452

Wals, A.E.J., \& Benavot, A. (2017). Can we meet the sustainability challenges? The role of education and lifelong learning. European Journal of Education Research, Development and Policy, 52(4), 404-413. DOI: 10.1111/ejed.12250

Cite this article: Birdsall S and White P (2020). Making connections: creating relationships with nonhuman nature, place and community. Australian Journal of Environmental Education 36, 197-199. https://doi.org/10.1017/aee.2020.35 